\title{
Molecular characterization of eukaryotic algal communities in the tropical phyllosphere based on real-time sequencing of the $18 \mathrm{~S}$ rDNA gene
}

\author{
Huan Zhu', Shuyin Li ${ }^{1}$, Zhengyu Hu ${ }^{2}$ and Guoxiang Liu ${ }^{1 *}$ (D)
}

\begin{abstract}
Backgroud: Foliicolous algae are a common occurrence in tropical forests. They are referable to a few simple morphotypes (unicellular, sarcinoid-like or filamentous), which makes their morphology of limited usefulness for taxonomic studies and species diversity assessments. The relationship between algal community and their host phyllosphere was not clear. In order to obtain a more accurate assessment, we used single molecule real-time sequencing of the $18 \mathrm{~S}$ rDNA gene to characterize the eukaryotic algal community in an area of South-western China.

Result: We annotated 2922 OTUs belonging to five classes, Ulvophyceae, Trebouxiophyceae, Chlorophyceae, Dinophyceae and Eustigmatophyceae. Novel clades formed by large numbers sequences of green algae were detected in the order Trentepohliales (Ulvophyceae) and the Watanabea clade (Trebouxiophyceae), suggesting that these foliicolous communities may be substantially more diverse than so far appreciated and require further research. Species in Trentepohliales, Watanabea clade and Apatococcus clade were detected as the core members in the phyllosphere community studied. Communities from different host trees and sampling sites were not significantly different in terms of OTUs composition. However, the communities of Musa and Ravenala differed from other host plants significantly at the genus level, since they were dominated by Trebouxiophycean epiphytes.

Conclusion: The cryptic diversity of eukaryotic algae especially Chlorophytes in tropical phyllosphere is very high. The community structure at species-level has no significant relationship either with host phyllosphere or locations. The core algal community in tropical phyllopshere is consisted of members from Trentepohliales, Watanabea clade and Apatococcus clade. Our study provided a large amount of novel $18 \mathrm{~S}$ rDNA sequences that will be useful to unravel the cryptic diversity of phyllosphere eukaryotic algae and for comparisons with similar future studies on this type of communities.
\end{abstract}

Keywords: Aerial algae, Community structure, Diversity, Phyllosphere, Phylogeny, SMRT sequencing, Tropical forest

\section{Background}

The phyllosphere comprises the aerial parts of plants and is mainly constituted by the leaves, which can be considered an ephemeral environment [1]. Organisms inhabiting the phyllosphere often suffer an oligotrophic stress due to direct exposure to atmosphere. In tropical

\footnotetext{
* Correspondence: liugx@ihb.ac.cn

'Key Laboratory of algal Biology, Institute of Hydrobiology, Chinese Academy of Sciences, Wuhan 430072, People's Republic of China

Full list of author information is available at the end of the article
}

rainforests, the prevailing epiphytes living as inhabitants of the phyllosphere consist of various bacteria, lichens, fungi, free-living algae and bryophytes [2-4]. The microbiomes formed by these organisms often produce patches of different colors (i.e. green, grey-green, yellow or orange), mainly due to primary or secondary pigments of different algae or lichens.

Most studies on microbial life in the phyllosphere have focused on bacteria and fungi. The composition of their communities, their adaptions to the phyllosphere and

(c) The Author(s). 2018 Open Access This article is distributed under the terms of the Creative Commons Attribution 4.0 International License (http://creativecommons.org/licenses/by/4.0/), which permits unrestricted use, distribution, and 
multiple interactions have been investigated [1, 5-8]. However, the algal communities of the phyllosphere have been less intensively studied. It has been shown that these epiphyllous forms represent a very heterogeneous and evolutionarily diverse assemblage, which mainly consist of cyanobacteria and green microalgae such as coccoid trebouxiophycean algae and branched trentepohliacean algae $[9,10]$. Since most algae are aquatic, these epiphyllous forms have generally received little attention in the past and their taxonomic and ecological knowledge has rapidly increased in recent years [11-15]. Cultivation-independent studies reported that eukaryotic algae are abundant on rainforest leaves, and the available knowledge about these forms suggests that there may be a huge number of unknown species [16-19]. Furthermore, it has been proved that coccoid green algae with identical or almost identical morphologies may be substantially different from the genetic point of view, and that single-celled coccoid microchlorophytes represent a polyphyletic complex of cryptic species [20-22]. Most coccoid green algae or SSU rDNA sequences retrieved from leaves are nested into trebouxiophycean clades corresponding to the genera Chlorella, Auxenchlorella, Myrmecia, Coccomyxa, Elliptochloris, Diplosphaera, Stichococcus, Prasiola, Trebouxia and Asterochloris [15, 23-28], whereas filamentous green algae belong to the genera Phycopeltis, Cephaleuros, Trentepohlia and Klebsormidium [9, 17, 29, 30]. Additionally, the Xanthophyceaen genus Heterococcus was also reported as phycobiont in lichens [26].

Given that phyllosphere microbiota play an unequivocal role in the functioning of forest ecosystems, it is remarkable how little we know about their diversity and distribution patterns [31]. It is therefore urgent to get a better characterization of the diversity of foliicolous algal communities. Some studies have investigated the taxonomy or diversity of several subaerial algal communities using morphological methods, and cultivation or various cultivation-independent molecular methods (i.e. clone library and Sanger sequencing) [14, 32]. The traditional approaches (e.g. morphological observation, and cultivation-independent molecular clone) are affected by several problems (i.e. low efficiency to get massive sequences, and some species difficult to grow in culture) and are inadequate to unravel the full diversity of these communities. The widely used high-throughput platforms (i.e. 454 and MiSeq) generate moderate to high numbers of high-quality short sequences, which are often not sufficient to obtain well-resolved results. The communities characterized by these platforms often suffer from low resolution of taxonomic coverage. The SSU rDNA gene is the molecular marker for which the largest amount of sequence data is available and is usually adequate for inference at genus level. Using nearly whole length SSU can provide a highly-resolved assessment of the taxonomic composition and diversity of communities.

In present study, we collected samples of 40 epiphyllous communities from the Xishuangbanna Tropical Botanical Garden (Yunnan, Southern China) in order to investigate comprehensively their diversity and characterize it with high resolution. We selected two pairs of primers to amplify the SSU sequences. In order to obtain well-resolved results, we used single molecular real-time (SMRT) to sequence our PCR products. Based on the results obtained, we assessed the taxonomic composition and molecular diversity of the 40 epiphyllous algal communities sampled.

\section{Results}

Taxonomic diversity across different phyllospheres

After deletion of the ambiguous and low-quality sequences (unambiguous sequences less than $1500 \mathrm{bp}$ long and chimeric sequences), we obtained a total of 152,324 high quality sequences. The frequency of the sequences lengths is plotted for the 152,324 high quality sequences in Additional file 1: Figure S1; most sequences were distributed at 1650 to 1850 bp length. We obtained 19,831 OTUs under $98 \%$ similarity cutoff level. The sampling intensity was evaluated. Random sub sampling was conducted for sequencing depths from 0 to 700 with steps of 100 sequences per sample. The rarefaction curve showed that our sequencing depth was sufficient (Additional file 2: Figure S2). A BLASTn was performed for annotation all 19,831 OTUs. Among them, 2922 were annotated as eukaryotic algae and mainly consisted of Trebouxiophyceae and Trentepohliales, with a very small part as Chlorophyceae (Volvocales and Jenufa clade), Eustigmatales and Gymnodiniales (Fig. 1). The present study was focused on eukaryotic algae, so we did not consider other microbial groups.

Sequences with the highest similarity to each OTU in GenBank were retrieved by BLASTn searches and then downloaded for further phylogenetic analysis. Finally, matrices with 1283, 1922, 194, 93 and 64 sequences respectively consisting of Trebouxiophyceaen, Trentepohliacean, Chlorophycean, Dinophycean and Eustigmatophyceaen OTUS, were used for phylogenetic analyses, in which Oedogoniales and Volvocales, Cladophorales, Oedogoniales, Perkinsus and Xanthophyceae were respectively used to select roots.

Phylogenetic analysis showed that the Trebouxiphycean OTUs mainly belonged to 6 independent clades, i.e., Prasiolales clade, Microthamniales clade, Apatococcus clade, Watanabea clade (including Mysteriochloris, Heveochlorella, Heterochlorella, Phyllosiphon, Polulichloris, Desertella, Kalinella, Parachloroidium and Symbiochloris groups), Trebouxiales clade (including Xylochloris, Eremochloris, Dictyochloropsis and Trebouxiales) and CBCE clade (Coccomyxa, Botryococcus, Choricystis and Elliptochloris) clade. Our phylogenetic analysis 

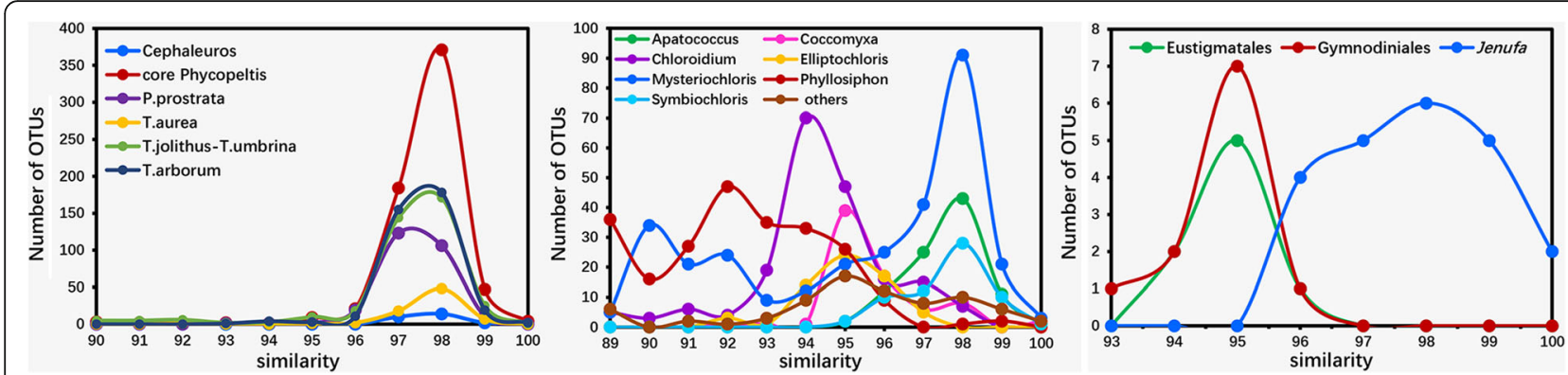

Fig. 1 Similarity of most eukaryotic algae OTUs based on BLASTn analysis

of Trebouxiophyceae showed that the Trebouxiophycean OTUs belonged primarily to 43 clades (Fig. 2, red clades), of which 39 clades are well supported.

The topology obtained from Maximum-likelihood analysis of Trentepohliales is shown in Fig. 3. Besides major lineages (Cephaleuros, Stomatochroon, Trentepohlia arborum clade, $T$. aurea, $T$. jolithus clade, $T$. annulata clade, core Phycopeltis, P. prostrata clade et al.) recovered from previous studies [33, 34], we also designated several novel lineages. In present phylogenetic analysis, the genera Trentepohlia and Phycopeltis were still paraphyletic. With the focus on Phycopeltis and its relative clades, the core Phycopeltis clade may be still monophyletic with the richest OTUs, which is in accordance with our expectation. The unexpected result is several novel deep lineages recovered including previously defined $P$. prostrata clade. OTUs fall into those novel lineages have an identity with their closest relatives about 91 to $94 \%$.

All Chlorophyceaen OTUs were nested into the Jenufa clade (incertae sedis) and in the Volvocales. And those OTUs did not form monophyletic group but clustered with their relatives retrieved from database (Fig. 4). 22 and 6 OTUs were annotated as Jenufa clade and Volvocales respectively (2 in Reinhardtia clade and 4 in Stephanosphaerinia clade). There were 11 and 9 OTUs annotated as Dinophycean and Eustigmatophycean groups, respectively. Both Dinophycean and Eustigmatophyceaen OTUs formed monophyletic groups sister to Gymnodiniales sensu stricto and Monodopsis (Monodopsidaceae) respectively (Fig. 5).

\section{Composition of algal communities from the phyllosphere in the studied area}

Among the 2922 OTUs from all samples, filamentous forms (Trentepohliales) represented the highest percentage of taxa, about $60 \%$ with 1790 . In the unicellular group (1132 OTUs), the Mysteriochloris group had the highest percentage (28\%), followed by the Parachloroidium group (15\%), Apatococcus group (14\%), Heveochlorella group (13\%), Elliptochloris group (11\%), Phyllosiphon group (9\%), Coccomyxa group (4\%), Symbiochloris group (2\%), and Jenufa group (1\%) (Fig. 6).
The alpha diversity of all 40 samples were showed in Additional file 3: Figure S3, including richness (number of OTUs), Shannon diversity and Simpson diversity. The number of observed OTUs and algal abundance among 10 host trees were 566 to 934 and 7248 to 12,466, respectively (Additional file 4: Figure S4), and among 5 different sampling locations were 1085 to 1321 and 17,983 to 22,844 (Additional file 5: Figure S5). The ANOVA analysis and nonmetric multidimensional scaling (NMDS) analysis showed the alpha-diversity and beta-diversity of algal community structures at species level has no significant difference between different host trees and different sampling locations (Table 1 and Fig. 7).

Similarity Profile Analysis results showed that the ten communities at genus level formed five clades, three of which were significantly supported $(P<0.05$, in the color lines, Fig. 8). Obviously, most host trees have a community dominated by algae of the core Phycopeltis clade, namely, Camellia, Caryota, Artocarpus, Dimocarpus (in green lines); Mangifera and Coffea have a community in which the Trentepohlia arborum clade and the core Phycopeltis clade are dominant. Musa and Ravenala differed from other trees in having a community dominated by coccoid algae (i.e., Mysteriochloris clade, Heveochlorella clade, Apatococcus clade and Elliptochloris clade); in these two plants Trentepohliales had a very low abundance.

In present study, we detected a core phyllosphere algal microbiome of common and abundant eukaryotic algae taxa present at all sites. The venn analysis showed that $56.45 \%$ (1689 OTUs) of the unique sequences were detected at two sites (Fig. 9), and only 8.26\% (247 OTUs) were found at all 5 sampling sites (Fig. 9). These 247 OTUs were assigned to five clades, i.e., Trentepohliales clade, Watanabea clade, Apatococcus clade, Jenufa clade and Volvocales clade. It could be easily found that Trentepohlialean OTUs and Watanabea OTUs had the highest abundance followed by Apatoccus clade OTUs, whereas OTUs of the Jenufa clade and Volvocales were lowest (Fig. 9). Thus, we concluded that the core algal microbiome of the phyllosphere in the study area mainly consisted of algae belonging to the Trentepohliales, Watanabea clade and Apatococcus clade. 


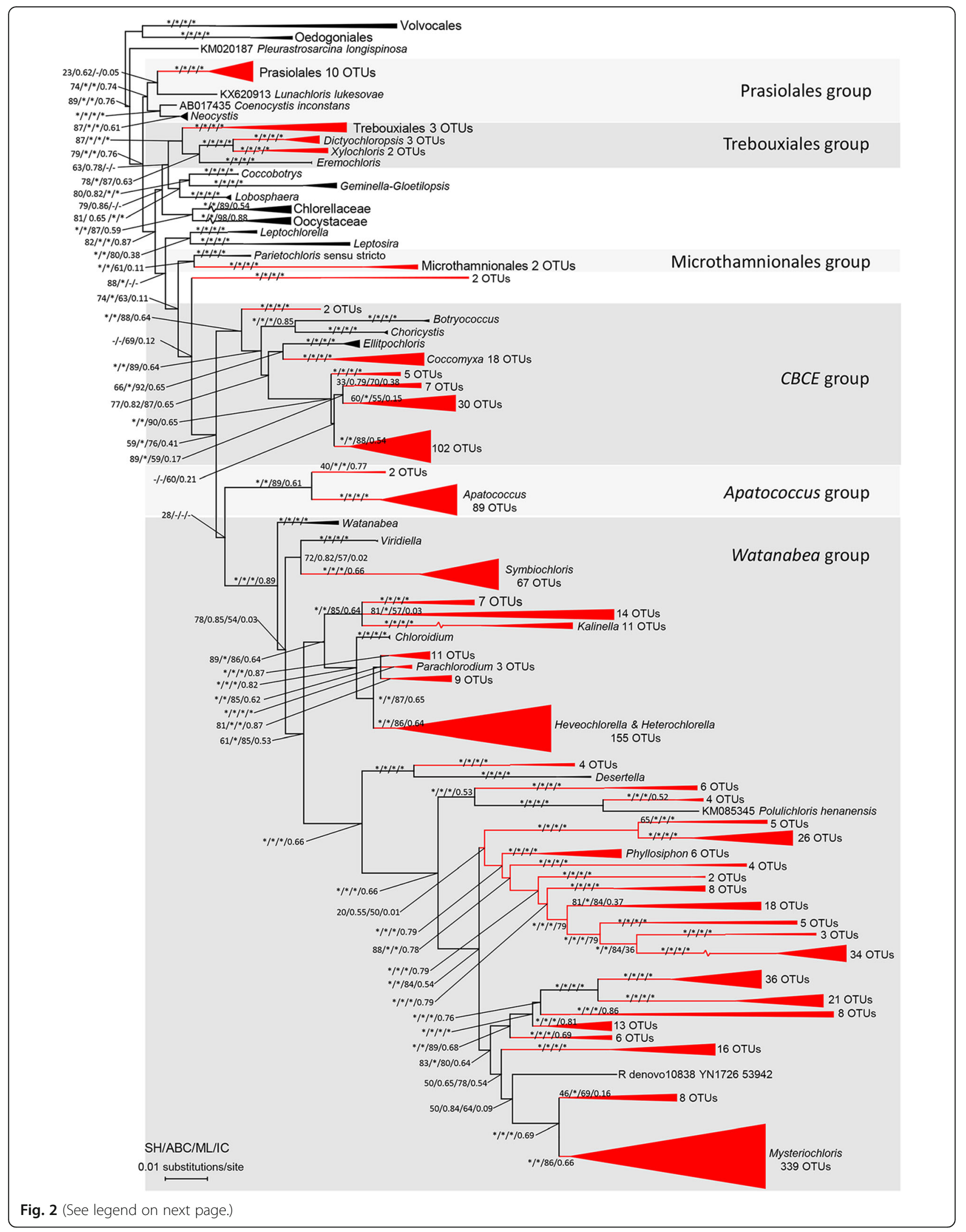


(See figure on previous page.)

Fig. 2 Maximum likelihood tree of Trebouxiophyceae showing phylogenetic relationships of Trebouxiophycean OTUs and sequences retrieved from GenBank (https://www.ncbi.nlm.nih.gov/genbank/). Branches with asterisks indicate statistical support from SH-test, aBayesian test, maximum-likelihood bootstrap and internodes certainty $\geq 90,0.90,90$ and 0.90 respectively. The tree was rooted by Chlorophycean Volvocales and Oedogoniales, and 6 order-level phylogroup were shaded in grey. Clades with present OTUs were colored in red

\section{Discussion}

A common identity threshold that has been used to delimit OTUs is 97\%; this threshold, however, has been mostly used for sequences of the $18 \mathrm{~S}$ rDNA V4 or V9 regions with a length about $150-450 \mathrm{bp}[35,36]$. The present study used sequences covering almost the whole length $18 \mathrm{~S}$ rDNA gene, which in our opinion makes our results more discriminating than results based only on the V4 or V9 region. We agree with previous studies remarking that a $98 \%$ identity threshold should provide a better taxonomic resolution that allows to investigate the interspecific diversity when using full $18 \mathrm{~S}$ rDNA sequences [37].

The present study examined 40 algal communities from ten different tropical host trees using nearly whole length of the 18S rDNA gene and provided an accurate characterization of the eukaryotic algal diversity of these communities. Our annotation results and phylogenetic results recovered five classes of eukaryotic algae in the phyllosphere, i.e., Trebouxiophyceae, Chlorophyceae, Ulvophyceae, Eustigmatophyceae and Dinophyceae. Many genera and species of Trebouxiophyceae, Trentepohliales and Eustigmatales are known predominantly from diverse aerial habitats, i.e., artificial substrates, tree trunks, leaves, wet soils and even desert soils [11, 14, 26, 38-41]. As one of the least known algal habitats world-wide, the identification of those group from phyllosphere is difficult due to their uncertainties in taxonomy and large cryptic diversity [2]. The possibly undescribed and unidentified green algae in tropical forests could be about $60 \%$ according to traditional morphological criteria [17]. According to our results, it is likely that this percentage may be far higher than $60 \%$. For example, there are about 80 species currrently recorded for the Trentepohliales and there are about 26 species in the Watanabea clade as defined on morphological basis (belonging to the genera Watanabea, Desertella, Heveochlorella, Heterochlorella, Phyllosiphon, Chloroidium, Parachloroidium, Polulichloris, Kalinella and Mysteriochloris) (http://www.algaebase.org; searched on May, 2018). Our results unravel a much higher diversity of $18 \mathrm{~S}$ rDNA than expected in phyllosphere community, especially in Watanabea clade and Trentepohliales.

The order Trentepohliales is a group of strictly subaerial algae that, besides free-living forms, include epiphytic or endophytic forms as well as lichen phycobionts. Recent phylogenetic studies of this group recovered at least seven lineages i.e., Cephaleuros, Stomatochroon, Trentepohlia arborum clade, T. aurea clade, core Phycopeltis clade, and several other Trentepohlia clades (such as T. jolithus clade, T. umbrina clade and $T$. annulata clade). Our knowledge about the phylogeny of Trentepohliales so far has been substantially limited by the fact that most sequence data come from cultured strains and limited environmental DNA sequences [42]. Many species of the order cannot be successfully cultured in the lab (especially of the genus Phycopeltis, which is mostly epiphytic on leaves). Our result once again indicates that Phycopeltis and Trentepohlia are polyphyletic. Additionally, our phylogenetic analysis demonstrates that the seven lineages so far discovered represent only a very small part of the trentepohlialean $18 \mathrm{~S}$ rDNA diversity. Our analysis recovered several lineages previously not identified in $18 \mathrm{~S}$ rDNA phylogenies; we consider that these lineages are likely to include undescribed species. Further studies of on foliicolous Trentepohliales based on methods such as single cell PCR may allow to get new insights and reassess the classification of this order.

Many of Trebouxiophycean algae are reported from terrestrial environments or as symbionts and endosymbionts with independent evolutions, i.e., Lunachloris, Choricystis, Trebouxia, Symbiochloris and Xylochloris [19, 43-45]. Molecular phylogenies of this class recovered four orders (Chlorellales, Trebouxiales, Prasiolales, Microthamnionales) and several not well-defined clades, i.e., Neocystis-Coenocystis clade, Apatococcus clade, Coccobotrys clade, Choricystis-Botryococcus-Coccomyxa clade, Elliptochloris clade, Eremochloris clade, Xylochloris clade and Watanabea clade [11, 22, 45, 46]. Nearly all these distinct lineages and orders include genera or species from terrestrial habitats. The Trebouxiophycean OTUs in the present study were distributed in 6 main clades (consisted of 43 well supported small clades). The many species of the genera Stichococcus and Apatococcus are frequently encountered in aerial habitats [47-49], and species of Trebouxia, Elliptochloris and Symbiochloris were described as symbionts of epiphytic lichens $[44,50,51]$, so it is not unexpected that we obtained OTUs referable to these genera or clades. Although for some genera and species of Trebouxiophyceae the classification is still confused, the discovery in the present study of new clades in Symbiochloris, Elliptochloris and the Trebouxiales clades leads us to suspect that the molecular diversity in these taxa is far higher than appreciated so far.

The Watanabea clade as morphologically circumscribed includes genera mainly found in aerial habitats such as surface of tree bark or leaves, i.e., Watanabea, 


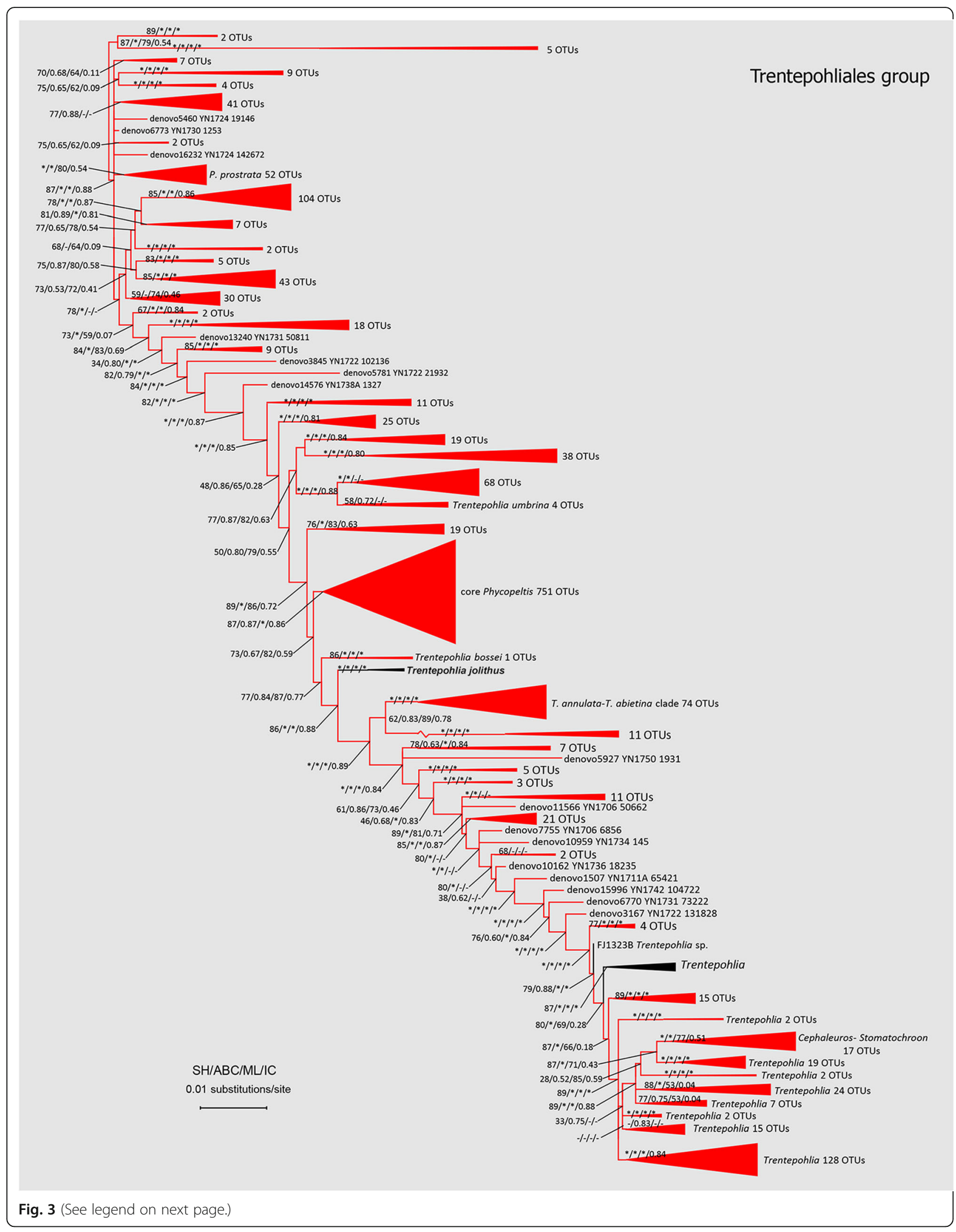


(See figure on previous page.)

Fig. 3 Maximum likelihood tree of Trentepohliales showing Phylogenetic relationships of new obtained Trentepohliacean OTUs and sequences retrieved from GenBank (https://www.ncbi.nlm.nih.gov/genbank/). Branches with asterisks indicate statistical support from SH-test, aBayesian test, maximum-likelihood bootstrap and internodes certainty $\geq 90,0.90,90$ and 0.90 respectively. The tree was rooted by the deep lineage recovered in phylogenetic analysis which Cladophorales were used as outgroup. Clades with present OTUs were colored in red

Viridiella, Chloroidium, Parachloridium, Heveochlorella, Heterochlorella, Kalinella, Polulichloris and Mysteriochloris [20, 52-57], most of which with limited $18 \mathrm{~S}$ rDNA sequences published in database (such as genera Mysteriochloris, Polulichloris and Kalinella). According to our results, the Symbiochloris clade also falls into the traditional Watanabea clade, in contrast to previous studies [44]. The bulk of novel sequences in the present study have a maximum similarity from 89 to $95 \%$ with published sequences of traditional Watanabea clade, especially the genera Mysteriochloris, Phyllosiphon and Heveochlorella. Thus, the large genetic distance rendered the traditional order level Watanabea clade and its sub-branches such as Mysterchloris, Phyllosiphon, Parachloroidium and Heveochlorella clades should be re-evaluated in further study.
It was not surprising that some Jenufa clade and Volvocales sequences were discovered in our study, since species of Jenufa are recorded from tropical or subtropical forests $[18,58]$ and Protosiphon species (fall into Stephanosphaerinia clade) are also reported from aerial habitats such as soils $[40,59]$. There are only 4 species in Jenufa, and only 2 OTUs have a $100 \%$ similarity with published sequences. Most OTUs are similar with those published sequences at 95-99\% level, which indicates that Jenufa clade need further deep diversity investigation.

It has been reported that heterokont algae such as Xanthophyceae and Eustigmatophyceae occur in aerial habitats, i.e. surface of rocks or corticolous communities of forest, free-living or lichenized [43]. Eustigmatophyceae have been rarely recorded, and usually thought to comprise a few genera and species belonging to two

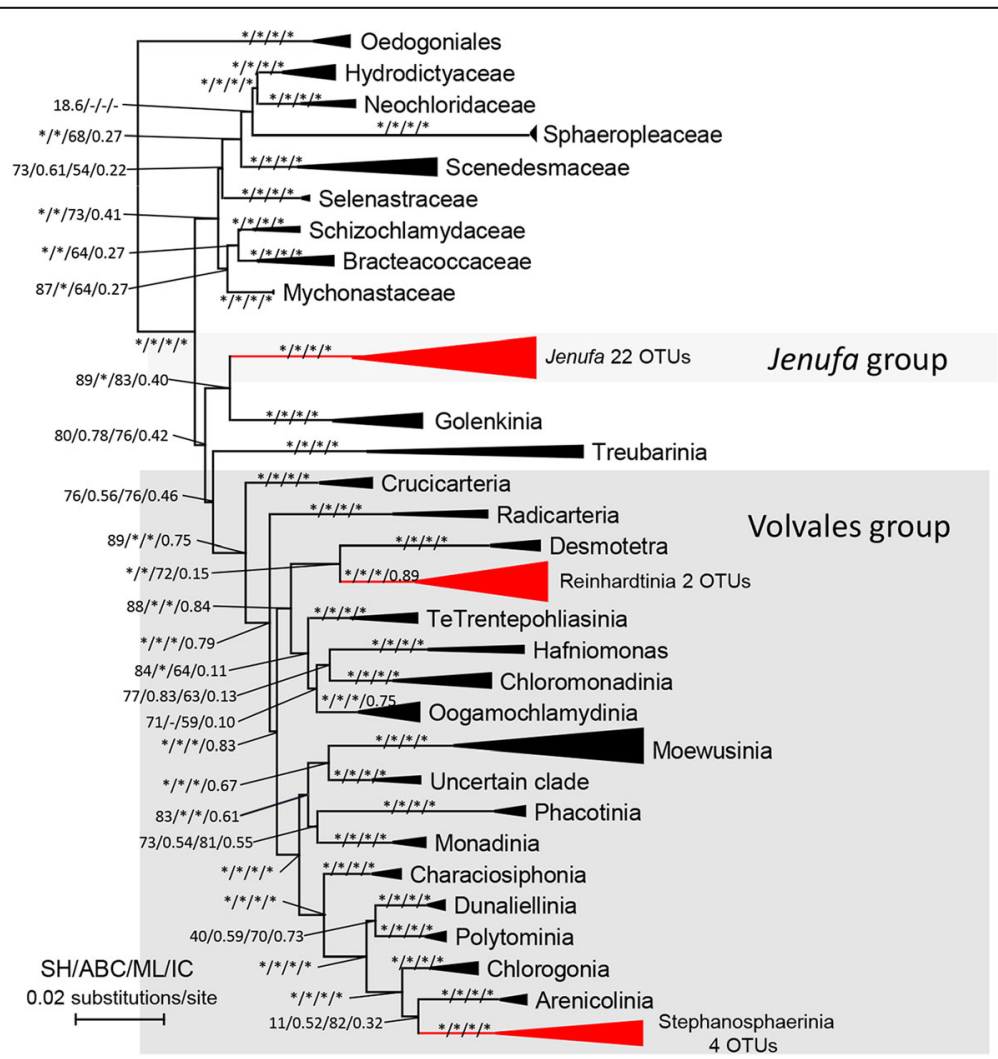

Fig. 4 Maximum likelihood tree of Volvocales showing phylogenetic relationships of new obtained Volvocales and Jenufa clade OTUs and sequences retrieved from GenBank (https://www.ncbi.nlm.nih.gov/genbank). Branches with asterisks indicate statistical support from SH-test, aBayesian test, maximum-likelihood bootstrap and internodes certainty $\geq 90,0.90,90$ and 0.90 respectively. The tree was rooted by Oedogoniales. Clades with present OTUs were colored in red 


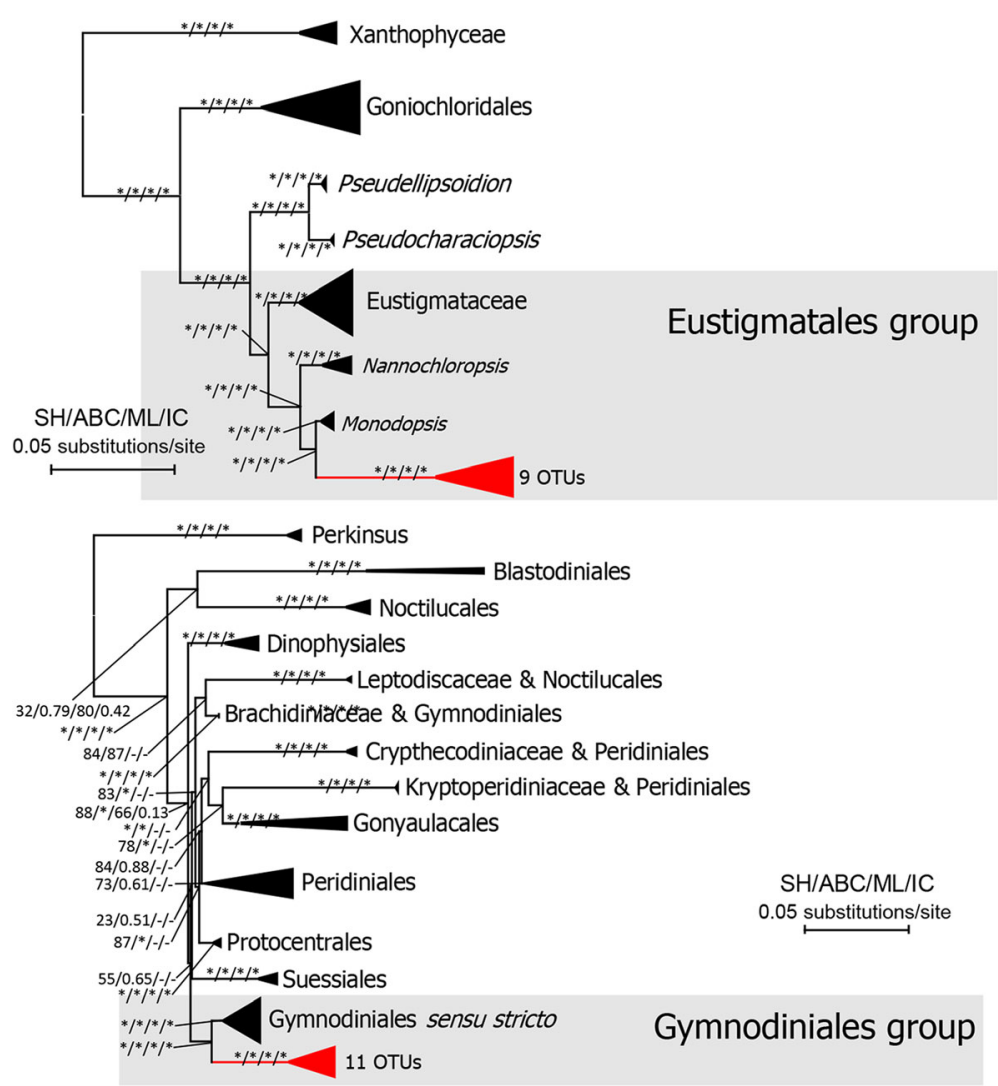

Fig. 5 Maximum likelihood trees of Eustigomatophycea (A) and Dinophyceae (B) showing phylogenetic relationships of new obtained Eustigmatales and Gymnodiniales OTUs and sequences retrieved from GenBank (https://www.ncbi.nlm.nih.gov/genbank/). Branches with asterisks indicate statistical support from SH-test, aBayesian test, maximum-likelihood bootstrap and internodes certainty $\geq 90,0.90,90$ and 0.90 respectively. The tree was rooted by Oedogoniales. Clades with present OTUs were colored in red

orders, Eustigmatales and Goniolchloridales [60]. The present environmental sequences formed a new clade sister to Monodopsis, demonstrating that the eustigmatophyceaen algae may have a large distribution and require further diversity investigation. The record of dinoflagellates sequences from tropical forest leaves was an unexpected result. Surprisingly, this is the first record of dinophytes from tropical forest leaves. These foliicolous dinoflagellate may represent a new group, since the 11 dinophyte OTUs formed a clade closely related to Gymnodiniales sensu stricto in the present study.

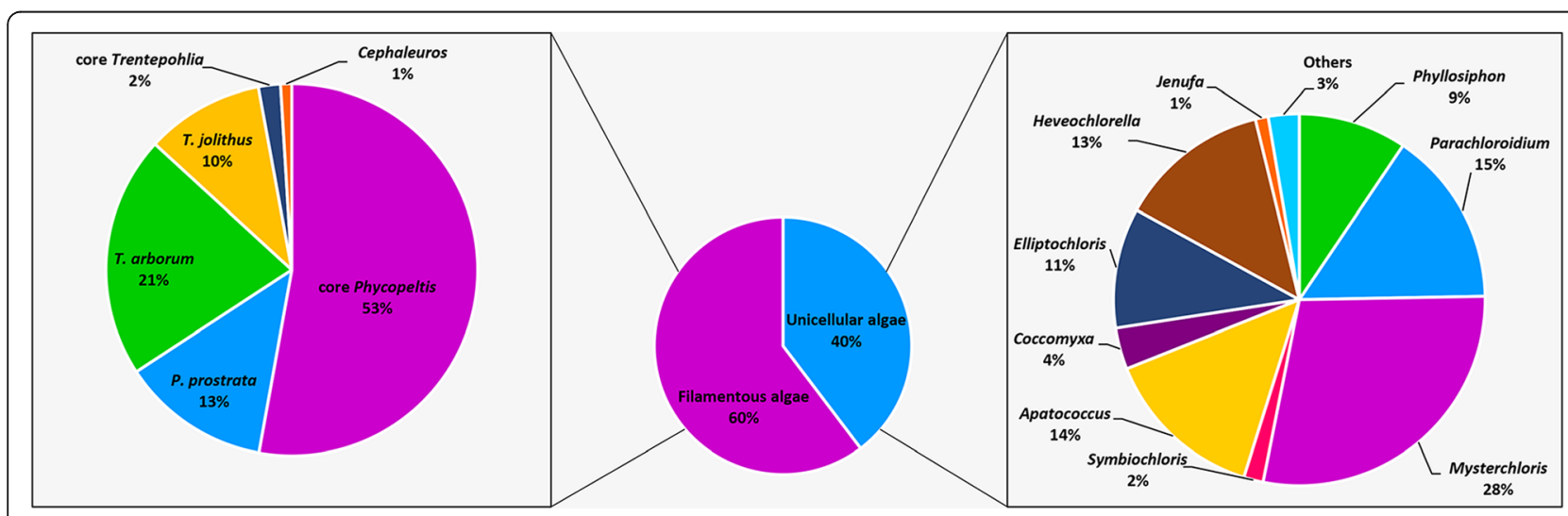

Fig. 6 Taxonomic structure and diversity of the reads mapping to eukaryotic algae assigned at genus-level 
Table 1 Two-way ANOVA analysis of effects of host species and sampling locations. $(\mathrm{P}<0.05$ was considered as statistically significant)

\begin{tabular}{|c|c|c|c|c|c|c|}
\hline & \multicolumn{2}{|c|}{ Host species } & \multicolumn{2}{|c|}{ Location } & \multicolumn{2}{|c|}{ Species*Location } \\
\hline & $\mathrm{F}$ & $p$ & $\mathrm{~F}$ & $p$ & $\mathrm{~F}$ & $p$ \\
\hline Shannon index & 1.29 & 0.34 & 2.56 & 0.09 & 1.46 & 0.26 \\
\hline Simpson index & 0.63 & 0.75 & 1.65 & 0.23 & 1.23 & 0.37 \\
\hline Richness & 1.82 & 0.17 & 1.86 & 0.18 & 0.8 & 0.66 \\
\hline Abundance & 1.69 & 0.2 & 1.5 & 0.26 & 0.79 & 0.67 \\
\hline
\end{tabular}

We did not detect any OTUs referable to another "flagship" aerial group, the Klebsormidiales, algae which are commonly found on most aerial surfaces and thrive on artificial substrates such as old walls [29, 47]. Species of Klebsormidiales have been rarely reported from tropical forest leaves. Maybe species of this group has no advantages in tropical phyllosphere algal community.

To our knowledge, this is the first study providing a comprehensive comparison of foliicolous algal communities based on a large-scale molecular dataset. Although the sampling sites were circumscribed to one forest garden, the eukaryotic algal diversity revealed through the $18 \mathrm{~S}$ rDNA gene in this environment is clearly very high. Usually coccoid algae do not occur on leaf surfaces as solitary cells but as aggregates, a situation very similar to bacteria [1]. The influence of the host trees on the fungal and bacterial communities is well known, and studies on these communities showed that the plant species is an important determinant $[7,61]$. Many studies proved that the abundance of bacteria and fungi was affected by plant species [61-63]. In contrast, the composition of the algal communities in terms of species/taxa (with OTU identity cutoff $98 \%$ ) is not significantly different in relation to host trees and locations according to our result.

Obviously, most host trees have a community dominated by Trentepohliales, in contrast, Musa and Ravenala have a coccoid green algae-dominant (especially Mysteriochloris and Elliptochloris and Heveochlorella) community. Thus, there is no significant difference among the community structure of Caryota, Chrysalidocarpus, Camellia, Artocarpus, Coffea, Mangifera and Dimocarpus either at species level or order level. However, community profiling at family or order level (same as clades defined in present study) showed striking differences between Musa, Ravenala and the other trees (Additional file 6: Figure S6). Since the eight Musa and the eight Ravenala were sampled from different sites, this does not seem to be a difference related to different sites. However, since we did not get information about host functional traits (such as leaf growth rate, concentration of metal ion, phosphorus and nitrogen) and the physiological requirements of those algae, it is hard to explain the correlation between Trebouxiophycean algae and Musa and Ravenala. Plants such as Musa and Ravenala have a cuticle that is thinner than other plants such as

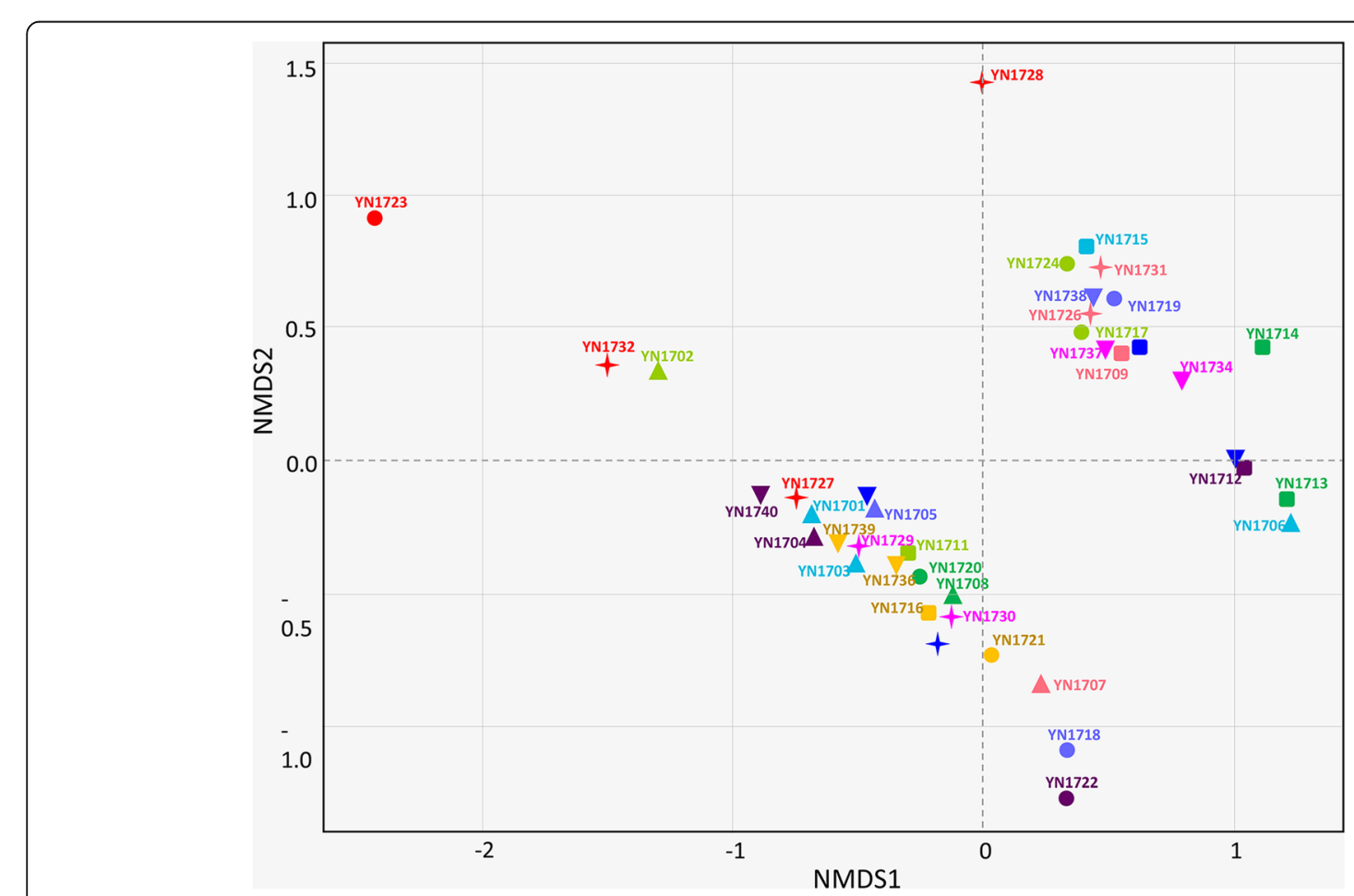

Fig. 7 Grouping of the 40 phyllosphere algal communities according to species-level taxonomic compositional similarity (Bray-Crutis distances) using nonlinear multidimensional scaling. Each symbol or color represents one sampling location or host tree 


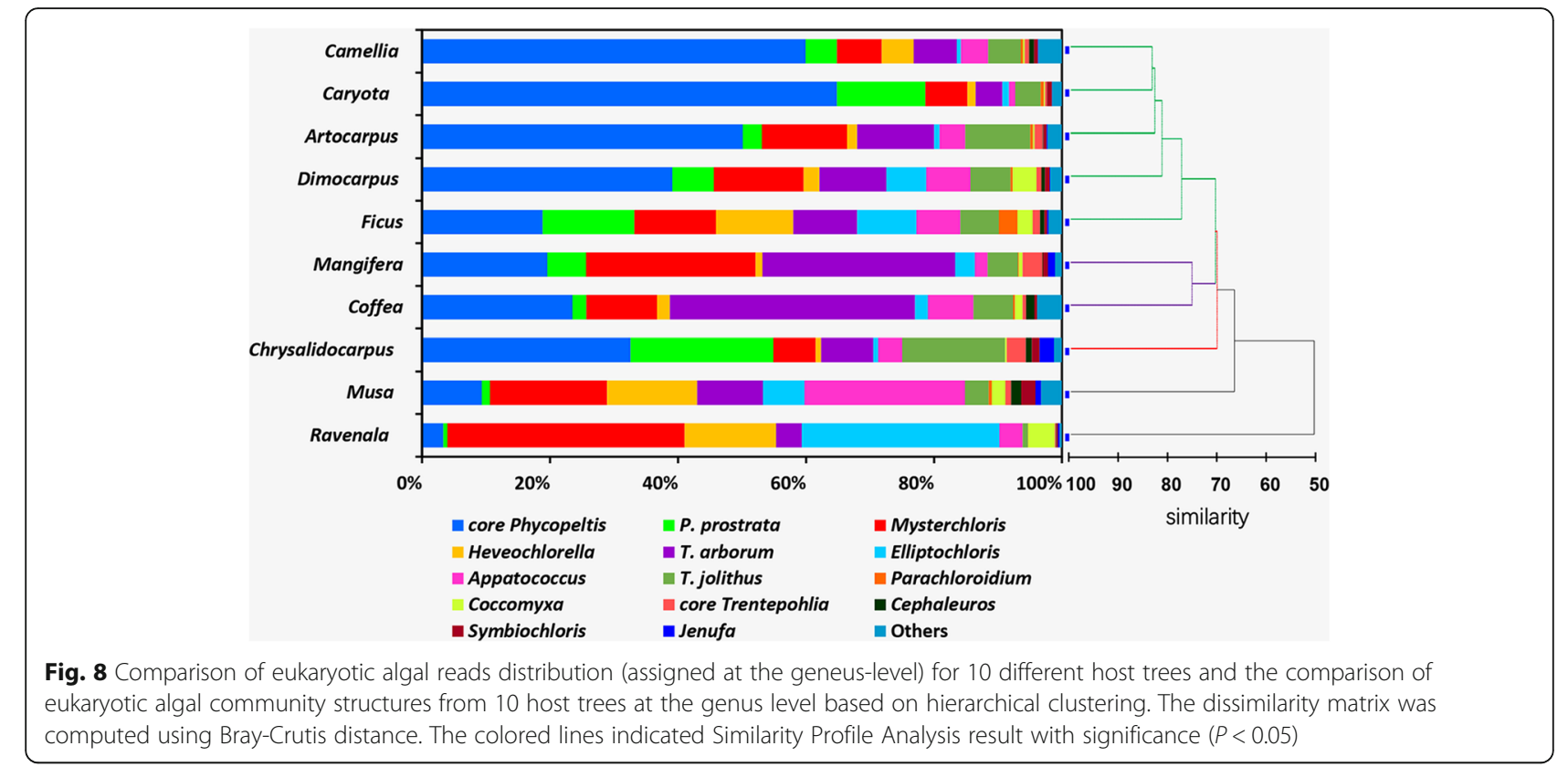

Caryota, Coffea, Dimocarpus and so on. Such leaves surfaces of Musa and Ravenala are not suitable for the survival of Phycopeltis because Phycopeltis is mainly found on very smooth surfaces such as leaf with thick cuticle (leathery leaf) and other abiotic substratum (plastic tags, i.e.), which leads to a community with dominant coccoid algae.

Previous studies reported that phylogenetic distance does not predict competition in the green algal communities, either in natural or experimental ones, which challenged the competition-related hypothesis [64, 65]. Although, such inference was concluded from phytoplankton communities, it seems also coincident with our observation of phyllosphere communities. Our result showed that interspecies diversity on same leaves was very rich, which, on the other hand, may predict that the strength of competition is not strong. Phylogenetic analyses of certain algae and their nearest relatives allow exploration of the number and rapidity of transitions to the habitat of interest and can provide insights into the physiological traits important in these transitions [39]. In present study, it has reported that algae in the Watanabea clade were reported to contain several mycosporine-like amino acids (MAAs) for surviving from excessive ultra-violet radiation [66]. Future studies on the physiology of those algae may provide more clues to understand their adaptations to the phyllosphere.

\section{Conclusions}

SMRT sequencing is very useful for accurately profiling the phyllosphere algal communities. Our results showed

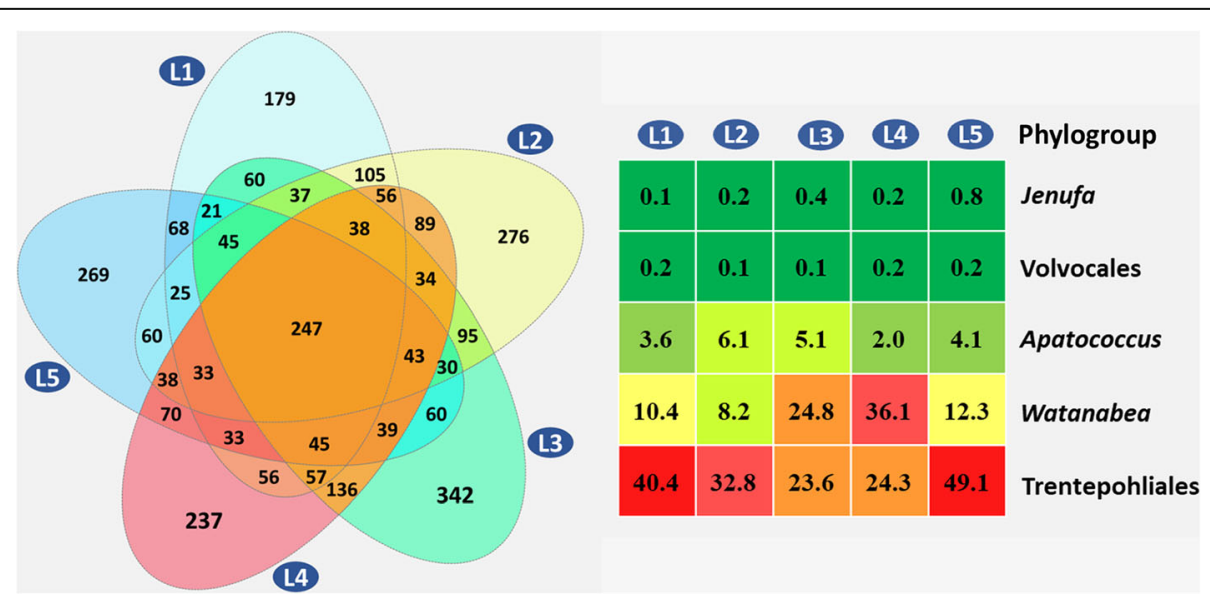

Fig. 9 The extent of overlap of algal communities between 5 locations showed in Venn diagram (left). And the abundance of the core algal microbiome, colors from green to red represent their abundance (right) 
that the diversity of eukaryotic algae is very high in tropical phyllosphere. There are still many undescribed species in such habitat, especially in Chlorophytes group. Trentepohliales, Watanabea clade and Apatococcus clade are the dominant algae in foliicolous communities from tropical forest. The community structure at the species level does not have a significant relationship either with their host plants or locations. Musa and Ravenala, with the leaf texture and growth rate different from other plants, differed from other host plants significantly at the genus level, since they were dominated by Trebouxiophycean epiphytes. The present study provided a large amount of novel $18 \mathrm{~S}$ rDNA sequences that will be useful to unravel the cryptic diversity of phyllosphere eukaryotic algae and for comparisons with similar future studies on this type of communities.

\section{Methods}

\section{Sampling sites and collection}

We collected eukaryotic algae from the leaf surfaces of land plants randomly in Xishuangbanna Tropical Botanical Garden in August 2017. The samples were collected from 5 sites (Fig. 10 and Additional file 7: Table S1); we collected 8 samples from each site. Each sample was collected at a distance of at least $10 \mathrm{~m}$ from all other samples. We selected ten different host trees (Mangifera, Artocarpus, Dimocarpus, Ficus, Coffea, Camellia, Chrysalidocarpus, Caryota, Musa and Ravenala). Each sample was collected $2 \mathrm{~m}$ above ground (thus we could not observe the positive surface to make sure all leaves were collected randomly) by clipping 2-6 leaves from an individual plant into Kraft paper bags from different site and different host tree. A total of 40 samples were collected in present study and brought to laboratory. The observable foliicolous masses were scraped slightly under a stereoscope using a small scalpel and a brush. Leaves devoid of evident algal coverage were cut into small fragments and shaken in small bags with diluted PBS (Phosphate Buffered Saline, $\mathrm{pH}=7.4$ ), then the microbial mass was pelted by centrifuging at $6000 \times \mathrm{g}$ for $10 \mathrm{~min}$. For each sample, a part of algal mass was dried by a vacuum freeze dryer and stored at $-80^{\circ} \mathrm{C}$. The remainders of the samples were dried using specimen clip and deposited in the Freshwater Algal Herbarium, Institute of Hydrobiology, Chinese Academy of Sciences, Wuhan.

\section{DNA extraction, amplification and sequencing}

The total DNA of each environmental mass (about 0.05 g) was extracted using the Omega higher plant DNA kit following its manual. We used two couples of universal SSU rDNA primers, NS1F and NS8R, NS1F and 1650R [67] to amplify the SSU rDNA gene. For both couples of primers, the thermal-cycling profiles were as follows: $94{ }^{\circ} \mathrm{C}$ for $5 \mathrm{~min}$, then 33 cycles of $94{ }^{\circ} \mathrm{C}$ for 30 s, $54{ }^{\circ} \mathrm{C}$ for $45 \mathrm{~s}$ and $72{ }^{\circ} \mathrm{C}$ for $60 \mathrm{~s}$, followed by a final extension at $72{ }^{\circ} \mathrm{C}$ for $6 \mathrm{~min}$. The products of each sample were mixed and purified with the QiaEX Gel Extraction Kit (Qiagen, Valencia, CA, USA) and sent to Shanghai Personal Biotechnology Co., Ltd. for SMRT sequencing by Pacbio Squeal platform. The products of each sample were assigned to unique forward and reverse barcode respectively, and then just one library was constructed for sequencing. We used circular consensus sequencing approach (CCS). With consensus sequencing at least three passes ( $\geq 3$ CCS), the average error rate was guaranteed to decrease theoretically less than $1.0 \%$. All sequences have

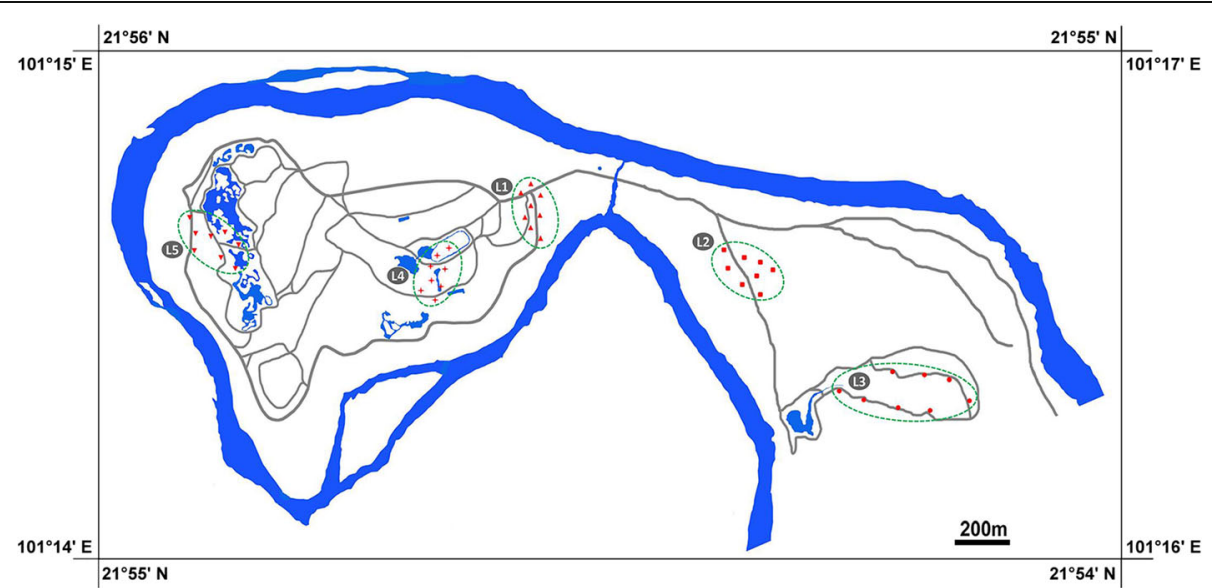

Fig. 10 Map of 5 sampling locations and 40 sampling sites from Xishuangbanna Tropical Botanical Garden (The map was drawn by the authors based on the information from National administration of surveying, mapping and geoinformation, http://www.sbsm.gov.cn/). Detailed sampling sites can be viewed at Additional file 7: Table S1 
been deposited in the SRA of the NCBI database under the accession no. SRP14140.

\section{Bioinformatic analysis}

Raw reads without adapter were assigned to different samples based on the barcodes (Additional file 8: Table S2). Any joined sequences with ambiguous bases (including sequences with more than 5 mismatches base-pairs at $5^{\prime}$ end and with more than 8 same sequential base-pairs and Chimera sequences) and lengths $<1500 \mathrm{bp}$ were discarded by QIIME (Quantitive Insigts Into Micriobial Ecology, v1.8.0) [68]. High-quality sequences were further processed using mothur (v. 1.34) following the recommendations by Schloss et al. [69]. Sequences were clustered into operational taxonomic units (OTUs) at a 98\% identity threshold. The representative sequences of each OTU were annotated by BLASTn, and only eukaryotic algal OTUs were processed consequently. All the representative sequences were assigned to five algal classes, namely Trebouxiophyceae, Ulvophyceae, Chlorophyceae, Dinophyceae and Eustigmatophyceae. OTUs with abundance lower than $0.001 \%$ were removed from the community data matrix but were retained for phylogenetic analysis.

\section{Taxonomic analysis of all OTUs}

Five matrices (Trebouxiophyceae, Ulvophyceae, Chlorophyceae, Dinophyceae and Eustigmatophyceae) were constructed by OTUs and tentative closely related sequences downloaded from GenBank (https://www.ncbi.nlm.nih.gov/ genbank/). The matrices were aligned by mafft 7.3 [70]. The best model for each matrix was selected using Modelfinder according to AIC criteria [71]. In present study, we performed Maximum Likelihood analysis by IQ-TREE [72] and used $\mathrm{SH}$ test and Internodes Certainty to evaluate the topology of the Maximum Likelihood tree. The UFboot2 method was used to perform bootstrap analyses under best-fit model [73]. For all five UFboot2 analysis, Bootstrap correlation coefficient of split occurrence frequencies was set to 0.99 . Then the Internodes Certainty was tested using bootstrap trees obtained from IQtree in RaxML [74].

According to results of the phylogenetic inference, we divided nearly all OTUs into 11 order-level phylogroups (named as Apatococcus group, Watanabea group, $C B C E$ group, Prasiolales group, Trebouxiales group, Microthamnionales group, Volvocales group, Jenufa group, Trentepohliales group, Eustigmatales group and Gymnodiniales group) for subsequent ecological analyses. OTUs were subdivided into two morphotypes, filamentous algae and unicellular algae.

\section{Statistical analysis}

Alpha diversity including the Shannon-Wiener index and Simpson's diversity index were calculated for each sample using the QIIME software. The venn analysis was performed in Venndiagram package [75] in $\mathrm{R}$ version 3.2 [76]. A two-way Analysis of Variance (ANOVA) was performed to test the effects of host trees and sampling sites on alpha diversity (number of OTUs, Shannon-Wiener index and Simpson's index) and the relative abundances of different algal taxa. ANOVA was performed using SPSS 18.0 package (SPSS, USA), with a $p$-value $<0.05$ selected for significance. The original data were normalized using standardization prior to statistical analysis and ANOSIM (Analysis of Similarities), SIMPROF (Similarity Profile Analysis) and NMDS (Non-parametric Multi-Dimensional Scaling) were performed using Primer 6.0 [77]. The resemblance of data matrix was measured by Bray-Curtis dissimilarity.

\section{Additional files}

Additional file 1: Figure S1. Lengths distribution of quality sequences. The frequency of the sequences length (in base-pairs) is plotted for the 152,324 sequences. (TIF $944 \mathrm{~kb}$ )

Additional file 2: Figure S2. Rarefaction analysis showing sampling intensity of 40 samples. Random sub-samplings were conducted for sequencing depth from 0 to 700 sequences. (TIF $1261 \mathrm{~kb}$ )

Additional file 3: Figure S3. The alpha diversity of 40 samples, including number of OTUs, Shannon diversity and Simpson diversity. (TIF 1927 kb)

Additional file 4: Figure S4. The alpha diversity of 10 host trees, including Richness (number of OTUs), Abundance (number of sequences), Shannon diversity and Simpson diversity. (TIF 705 kb)

Additional file 5: Figure S5. The alpha diversity of 5 sampling locations, including Richness (number of OTUs), Abundance (number of sequences), Shannon diversity and Simpson diversity. (TIF $541 \mathrm{~kb}$ )

Additional file 6: Figure S6. Nonlinear multidimensional scaling analysis of 40 phyllosphere algal community structures according to order-level taxonomic compositional similarity (Bray-Crutis distances). (TIF $850 \mathrm{~kb}$ )

Additional file 7: Table S1. Sampling sites of the 40 leaves specimens from Xishuangbanna Tropical Botanical Garden and quantity of obtained sequences from each sample. (DOCX $18 \mathrm{~kb}$ )

Additional file 8: Table S2. The 40 barcodes used to identify samples within the pooled sequencing run. (DOCX $15 \mathrm{~kb}$ )

\section{Abbreviations}

ANOSIM: Analysis of similarities; ANOVA: Analysis of variance; CCS: Circular consensus sequencing; MAAs: Mycosporine-like amino acids; NMDS: Nonparametric multi-dimensional scaling; OTUs: Operational taxonomic units; SIMPROF: Similarity profile analysis; SMRT: Single molecule real-time sequencing

\section{Acknowledgements}

Many thanks to Dr. Fabio Rindi from Università Politecnica delle Marche for his constructive comments on an early version of this manuscript.

\section{Funding}

This work was financially supported by grants from the National Natural Science Foundation of China (grant no. 31600168 and 31870189), and

Chinese Academy of Sciences Key deployment project (grant no. ZDRWZS2017-221). Both two supporters did not participate in design of the study, collection of specimens, analysis of data and writing the manuscript.

\section{Availability of data and materials}

The datasets supporting the conclusions of this article are included within the article and its Additional files. Samples were collected following 
guidelines compiled by Freshwater Algal Herbarium, Institute of Hydrobiology. All the dried samples were deposited in the Freshwater Algal Herbarium, Institute of Hydrobiology, Chinese Academy of Sciences. All sequences have been deposited in the SRA of the NCBI database under the accession no. SRP14140

\section{Authors' contributions}

$\mathrm{HZ}, \mathrm{GL}$ and $\mathrm{ZH}$ conceived the study. $\mathrm{HZ}$ and $\mathrm{SL}$ collected the samples and performed the experiment. $\mathrm{HZ}$ analyzed the data and wrote the manuscript. All authors have read and approved the manuscript.

\section{Ethics approval and consent to participate}

Not applicable.

\section{Consent for publication}

Not applicable.

\section{Competing interests}

The authors declare that they have no competing interests.

\section{Publisher's Note}

Springer Nature remains neutral with regard to jurisdictional claims in published maps and institutional affiliations.

\section{Author details}

${ }^{1}$ Key Laboratory of algal Biology, Institute of Hydrobiology, Chinese Academy of Sciences, Wuhan 430072, People's Republic of China. ${ }^{2}$ State Key Laboratory of Freshwater Ecology and Biotechnology, Institute of Hydrobiology, Chinese Academy of Sciences, Wuhan 430072, People's Republic of China.

Received: 26 May 2018 Accepted: 4 December 2018

Published online: 18 December 2018

\section{References}

1. Vorholt JA. Microbial life in the phyllosphere. Nat Rev Microbiol. 2012;10(12): $828-40$

2. Hoffmann L. Algae of terrestrial habitats. Bot Rev. 1989;55(2):77-105.

3. Gradstein SR. The taxonomic diversity of epiphyllous bryophytes. Community Ecol. 1997;21(1):15-9.

4. Lindow SE, Leveau JH. Phyllosphere microbiology. Ecology. 2002;13(3):23843.

5. Turner TR, James EK. Poole PS. Plant microbiome. Genome Biol. 2013;14:209.

6. Copeland JK, Yuan L, Layeghifard M, Wang PW, Guttman DS. Seasonal community succession of the phyllosphere microbiome. Mol Plant Microbe In. 2015;28(3):274-85.

7. Laforest-Lapointe I, Messier C, Kembel SW. Tree leaf bacterial community structure and diversity differ along a gradient of urban intensity. mSystems. 2017;2(6):e00087-17.

8. Morella NM, Gomez AL, Wang G, Leung MS, Koskella B. The impact of bacteriophages on phyllosphere bacterial abundance and composition. Mol Ecol. 2018;27:2025-38.

9. Neustupa J, Škaloud P. Diversity of subaerial algae and cyanobacteria growing on bark and wood in the lowland tropical forests of Singapore. Plant Ecol Evol. 2010;143(1):51-62

10. Leliaert F, Smith DR, Moreau H, Herron MD, Verbruggen $H$, Delwiche CF, Clerck OD. Phylogeny and molecular evolution of the Green algae. Crit Rev Plant Sci. 2012;31(1):1-46.

11. Rindi F, Allali HA, Lam DW, López-Bautista JM. An overview of the biodiversity and biogeography of terrestrial green algae. In: Rescigno $\mathrm{V}$, Maletta S, editors. Biodiversity Hotspots. New York: Nova Science Publishers: 2010. p. 105-22

12. Nelsen MP, Plata ER, Andrew CJ, Lücking R. Lumbsch HT. phylogenetic diversity of trentepohlialean algae associated with lichen-forming fungi. J Phycol. 2011;47(2):282-90.

13. Hametner C, Stocker-Wörgötter E, Rindi F, Grube M. Phylogenetic position and morphology of lichenized Trentepohliales (Ulvophyceae, Chlorophyta) from selected species of Graphidaceae. Phycol Res. 2014;62(3):170-86.

14. Hallmann C, Hoppert M, Mudimu O, Friedl T. Biodiversity of green algae covering artificial hard substrate surfaces in a suburban environment: a case study using molecular approaches. J Phycol. 2016;52(5):732-44.
15. Hodač L, Hallmann C, Spitzer K, Elster J, Faßhauer F, Brinkmann N, Lepka D, Diwan V, Friedl T. Widespread green algae Chlorella and Stichococcus exhibit polar-temperate and tropical-temperate biogeography. FEMS Microbiol Ecol. 2016:92(8):fiw122.

16. Neustupa J. The genus Phycopeltis (Trentepohliales, Chlorophyta) from tropical Southeast Asia. Nova Hedwigia. 2003;76(76):487-506.

17. Neustupa J, Škaloud P. Diversity of subaerial algae and cyanobacteria on tree bark in tropical mountain habitats. Biologia. 2008;63(6):806-12.

18. Němcová $Y$, Eliáš M, P Š, Hodač L, Neustupa J. Jenufa gen. Nov.: a new genus of coccoid green algae (Chlorophyceae, incertae sedis) previously recorded by environmental sequencing. J Phycol. 2011;47(4):928-38

19. Neustupa J, Eliáš M, Škaloud P, Němcová Y, Šejnohová L. Xylochloris irregularis gen. Et sp. nov. (Trebouxiophyceae, Chlorophyta), a novel subaerial coccoid green alga. Phycologia. 2011;50(50):57-66.

20. Darienko T, Gustavs L, Mudimu O, Menendez CR, Schumann R, Karsten U, Fried T, Pröschold T. Chloroidium, a common terrestrial coccoid green alga previously assigned to Chlorella (Trebouxiophyceae, Chlorophyta). Eur J Phycol. 2010;45(1): 79-95.

21. Luo W, Pröschold T, Bock C, Krienitz L. Generic concept in Chlorella-related coccoid green algae (Chlorophyta, Trebouxiophyceae). Plant Biol. 2010;12(3): $545-53$

22. Krienitz L, Bock C. Present state of the systematics of planktonic coccoid green algae of inland waters. Hydrobiologia. 2012;698(1):295-326.

23. Krienitz L, Hegewald EH, Hepperle D, Huss VAR, Rohr T, Wolf M. Phylogenetic relationship of Chlorella and Parachlorella gen. Nov. (Chlorophyta, Trebouxiophyceae). Phycologia. 2004;43(43):529-42.

24. Eliáš M, Neustupa J. Pseudomarvania, gen. Nov. (Chlorophyta, Trebouxiophyceae), a new genus for "budding" subaerial green algae Marvania aerophytica Neustupa et Šejnohová and Stichococcus ampulliformis Handa. Fottea. 2009:9(2):169-77.

25. Pröschold T, Darienko T, Silva PC, Reisser W, Krienitz L. The systematics of Zoochlorella revisited employing an integrative approach. Environ Microbiol. 2011;13(2):350-64

26. Thüs H, Muggia L, Pérez-Ortega S, Favero-Longo SE, Joneson S, O'Brien H, Nelsen MP, Duque-Thüs R, Grube M, Friedl T. Revisiting photobiont diversity in the lichen family Verrucariaceae (Ascomycota). Eur J Phycol. 2011;46(4): 399-415.

27. Sadowska-Deś AD, Grande FD, Lumbsch HT, Beck A, Otte J, Hur J. Integrating coalescent and phylogenetic approaches to delimit species in the lichen photobiont Trebouxia. Mol Phylogenet Evol. 2014;76(1): 202-10.

28. Darienko T, Gustavs L, Eggert A, Wolf W, Pröschold T. Evaluating the species boundaries of green microalgae (Coccomyxa, Trebouxiophyceae, Chlorophyta) using integrative taxonomy and dna barcoding with further implications for the species identification in environmental samples. PLoS One. 2015;10(6):e0127838.

29. Rindi F, Guiry M, López-Bautista JM. Distribution, morphology, and phylogeny of Klebsormidium (Klebsormidiales, Charophyceae) in urban environments in Europe. J Phycol. 2008:44(6):1529-40.

30. Rindi F, Lam DW, López-Bautista JM. Trentepohliales (Ulvophyceae, Chlorophyta) from Panama. Nova Hedwigia. 2008:87:421-44.

31. Green J, Bohannan BJM. Spatial scaling of microbial biodiversity. Trends Ecol Evol. 2006:21(9):501-7.

32. Procházková K, Némcová Y, Neustupa J. Phyllosiphon duini sp. nov. (Trebouxiophyceae, Chlorophyta), a species isolated from a corticolous phototrophic biofilm. Cryptogamie Algol. 2018;39(1):23-34.

33. Rindi F, Lam DW, López-Bautista JM. Phylogenetic relationships and species circumscription in Trentepohlia and Printzina (Trentepohliales, Chlorophyta). Mol Phylogenet Evol. 2009;52(2):329-39.

34. Zhu H, Hu Z, Liu G. Morphology and molecular phylogeny of Trentepohliales (Chlorophyta) from China. Eur J Phycol. 2017:52(3):1-12.

35. Vargas CD, Audic S, Henry N, Decelle J, Mahé F, Logares R, Lara E, Berney C, Bescot NL, Probert I. Eukaryotic plankton diversity in the sunlit ocean. Science. 2016:348:29223618-25.

36. Tragin M, Zingone A, Vaulot D. Comparison of coastal phytoplankton composition estimated from the $\mathrm{V} 4$ and $\mathrm{V} 9$ regions of the $18 \mathrm{~S}$ rRNA gene with a focus on photosynthetic groups and especially Chlorophyta. Environ Microbiol. 2018:20(2):506-20.

37. Caron DA, Countway PD, Savai P, Gast RJ, Schnetzer A, Moorthi SD, Dennett MR, Moran DM, Jones AC. Defining DNA-based operational taxonomic units for microbial-eukaryote ecology. Appl Environ Microb. 2009;75(18):5797-808. 
38. Thompson RH, Trentepohliales WDE. Cephaleuros, Phycopeltis, and Stomatochroon: morphology, taxonomy, and ecology. New Hampshire: Science Publishers; 1997. p. 1-149.

39. Lewis LA, Lewis PO. Unearthing the molecular phylodiversity of desert soil green algae (Chlorophyta). Syst Biol. 2005;54(6):936-47.

40. Lewis LA, Trainor FR. Survival of Protosiphon botryoides (Chlorophyceae, Chlorophyta) from a Connecticut soil dried for 43 years. Phycologia. 2012; 51(6):662-5

41. Song MA, Lee OM. A study of eight newly reported species of chlorophyte and Eustigmatophyte, Korea. J Ecol Environ. 2014;37(4):341-50.

42. Brooks FE, Rindi F, Suto Y, Ohtani S, Green M. The Trentepohliales (Ulvophyceae, Chlorophyta): an unusual algal order with a novel plant pathogen-Cephaleuros. Plant Dis. 2015;99(6):740-53.

43. Stifterova A, Neustupa J. Community structure of corticolous microalgae within a single forest stand: evaluating the effects of bark surface $\mathrm{pH}$ and tree species. Fottea. 2015;15(2):113-22.

44. Škaloud P, Friedl T, Hallmann C, Beck A, Grande FD. Taxonomic revision and species delimitation of coccoid green algae currently assigned to the genus Dictyochloropsis (Trebouxiophyceae, Chlorophyta). J Phycol. 2016;52(4):599-617.

45. Barcytè D, Hodač L, Nedbalová L. Lunachloris lukesovae gen. Et sp. nov. (Trebouxiophyceae, Chlorophyta), a novel coccoid green alga isolated from soil in South Bohemia, Czech Republic. Eur J Phycol. 2017;52(3):1-11.

46. Kulichová J, Škaloud P, Neustupa J. Molecular diversity of green corticolous microalgae from two sub-Mediterranean European localities. Eur J Phycol. 2014:49(3):345-55.

47. Hansj S, Caroline G, Opayi M. Assessing phylogenetic affinities and species delimitations in Klebsormidiales (Streptophyta): nuclear-encoded rDNA phylogenies and its secondary structure models in Klebsormidium, Hormidiella, and Entransia. J Phycol. 2008;44(1):183-95.

48. Gustavs L, Görs M, Karsten U. Polyol patterns in biofilm-forming aeroterrestrial green algae (Trebouxiophyceae, Chlorophyta). J Phycol. 2011; 47(3):533-7.

49. Zahradníková M, Andersen HL, Tønsberg T, Beck A. Molecular evidence of Apatococcus, including A. fuscideae sp. nov., as photobiont in the genus Fuscidea. Protist. 2017;168(4):425-38

50. Kroken S, Taylor JW. Phylogenetic species, reproductive mode, and specificity of the green alga Trebouxia forming lichens with the fungal genus Letharia. Bryologist. 2000;103:645-60.

51. Peksa O, Škaloud P. Do photobionts influence the ecology of lichens? A case study of environmental preferences in symbiotic green alga Asterochloris (Trebouxiophyceae). Mol Ecol. 2011;20(18):3936-48.

52. Neustupa J, Němcová $Y$, Eliáš M, Škaloud P. Kalinella bambusicola gen. Et sp. nov. (Trebouxiophyceae, Chlorophyta), a novel coccoid Chlorella-like subaerial alga from Southeast Asia. Phycol Res. 2009;57(3):159-69.

53. Ma S, Huss VAR, Tan D, Sun X, Chen J, Xie Y, Zhang J. A novel species in the genus Heveochlorella (Trebouxiophyceae, Chlorophyta) witnesses the evolution from an epiphytic into an endophytic lifestyle in tree-dwelling green algae. Eur J Phycol. 2013;48(2):200-9.

54. Neustupa J, Němcová Y, Veselá J, Steinová J, Škaloud P. Parachloroidium gen. Nov. (Trebouxiophyceae, Chlorophyta), a novel genus of coccoid green algae from subaerial corticolous biofilms. Phycologia. 2013;52(5):411-21.

55. Procházková K, Nmcová Y, Kulichová J, Neustupa J. Morphology and phylogeny of parasitic and free-living members of the genus Phyllosiphon (Trebouxiophyceae, Chlorophyta). Nova Hedwigia. 2015;101:501-18.

56. Song H, Zhang Q, Liu G, Hu Z. Polulichloris henanensis gen. Et sp. nov. (Trebouxiophyceae, Chlorophyta), a novel subaerial coccoid green alga. Phytotaxa. 2015;218(2):137-46.

57. Song H, Hu Y, Zhu H, Wang Q, Liu G, Hu Z. Three novel species of coccoid green algae within the Watanabea clade (Trebouxiophyceae, Chlorophyta) Int J Syst Evol Micr. 2016;66(12):5465-77.

58. Song H, Li S, Liu X, Wang Q, Zhu H, Liu G, Hu Z. Jenufa lobulosa sp. nov. (Chlorophyceae, Chlorophyta), a new epilithic, terrestrial species described from China. Phycologia. 2018;57(1):52-60.

59. Nakada T, Misawa K, Nozaki H. Molecular systematics of Volvocales (Chlorophyceae, Chlorophyta) based on exhaustive 18S rRNA phylogenetic analyses. Mol Phylogenet Evol. 2008;48(1):281-91.

60. Fawley KP, Eliáš M, Fawley MW. The diversity and phylogeny of the commercially important algal class Eustigmatophyceae, including the new clade Goniochloridales. J Appl Phycol. 2014;26(4):1773-82.
61. Knief C, Ramette A, Frances L, Alonsoblanco C, Vorholt JA. Site and plant species are important determinants of the Methylobacterium community composition in the plant phyllosphere. ISME J. 2010;4(6):719-28.

62. Whipps JM, Hand P, Pink D, Bending GD. Phyllosphere microbiology with special reference to diversity and plant genotype. J Appl Microbiol. 2008; 105(6):1744-55

63. Kembel SW, O'Connor TK, Arnold HK, Hubbell SP, Wright SJ, Green JL. Relationships between phyllosphere bacterial communities and plant functional traits in a neotropical forest. P Natl Acad Sci USA. 2014;111(38): 13715-20.

64. Narwani A, Alexandrou MA, Oakley TH, Carroll IT, Cardinale BJ. Experimental evidence that evolutionary relatedness does not affect the ecological mechanisms of coexistence in freshwater green algae. Ecol Lett. 2013;16(11): 1373-81.

65. Narwani A, Bentlage B, Alexandrou MA, Fritschie KJ, Delwiche C, Oakley TH, Cardinale BJ. Ecological interactions and coexistence are predicted by gene expression similarity in freshwater green algae. J Phycol. 2017;105(3):580-91.

66. Karsten U, Friedl T, Schumann R, Hoyer K, Lembcke S. Mycosporine-like amino acids and phylogenies in green algae: prasiola and its relatives from the Trebouxiophyceae (Chlorophyta). J Phycol. 2005;41(3):557-66.

67. White TJ, Bruns TD, Lee SB, Taylor JW. Amplification and direct sequencing of fungal ribosomal RNA genes for phylogenetics. In: Innis N, Gelfand D, Sninsky J, White TJ, editors. PCR-protocols and applications-a laboratory manual. New York: Academic; 1990. p. 315-22.

68. Caporaso JG, Kuczynski J, Stombaugh J, Bittinger K, Bushman FD, Costello EK, et al. QIIME allows analysis of high-throughput community sequencing data. Nat Methods. 2010;7:335-6.

69. Schloss PD, Westcott SL, Ryabin T, Hall JR, Hartmann M, Hollister EB, Lesniewski RA, Oakley BB, Parks DH, Robinson CJ. Introducing mothur: open-source, platform-independent, community-supported software for describing and comparing microbial communities. Appl Environ Microb. 2009;75(23):7537-41.

70. Katoh K, Standley DM. MAFFT multiple sequence alignment software version 7: improvements in performance and usability. Mol Biol Evol. 2013; 30(4):772-80.

71. Kalyaanamoorthy S, Minh BQ, Wong TKF, Haeseler AV, Jermiin LS. ModelFinder: fast model selection for accurate phylogenetic estimates. Nat Methods. 2017;14(6):587-9

72. Nguyen LT, Schmidt HA, Haeseler AV, Minh BQ. IQ-TREE: a fast and effective stochastic algorithm for estimating maximum-likelihood phylogenies. Mol Biol Evol. 2015;32(1):268-74.

73. Hoang DT, Chernomor O, Von AH, Minh BQ, Le SV. UFBoot2: improving the ultrafast bootstrap approximation. Mol Biol Evol. 2017;35(2):518-22.

74. Stamatakis A. RAxML version 8: a tool for phylogenetic analysis and postanalysis of large phylogenies. Bioinformatics. 2014;30(9):1312-3.

75. Chen $H$, Boutros PC. VennDiagram: a package for the generation of highlycustomizable Venn and Euler diagrams in R. BMC Bioinformatics. 2011;12(1): 35.

76. R Development Core team. R: a language and environment for statistical computing. R Foundation for statistical computing, Vienna, Austria. Computing. 2016;14:12-21.

77. Clarke KR, Gorley RN. Primer v6: User Manual/Tutorial. 2006.

Ready to submit your research? Choose BMC and benefit from:

- fast, convenient online submission

- thorough peer review by experienced researchers in your field

- rapid publication on acceptance

- support for research data, including large and complex data types

- gold Open Access which fosters wider collaboration and increased citations

- maximum visibility for your research: over $100 \mathrm{M}$ website views per year

At $\mathrm{BMC}$, research is always in progress.

Learn more biomedcentral.com/submissions 